\title{
DEVELOPMENT OF RENEWABLE ENERGY SOURCES IN THE CONTEXT OF ENERGY MANAGEMENT
}

\author{
VALENTYNA YAKUBIV, YULIIA MAKSYMIV, IRYNA HRYHORUK, NAZARIY POPADYNETS, \\ IRYNA PIATNYCHUK
}

\begin{abstract}
The paper deals with global trends in energy consumption and renewable energy generation. Worldwide practices in financing of renewable energy production are analysed according to the following dimensions: sources of financing, types of used policy instruments, types of recipients (public or private) and types of financed technologies. The key factors that influence the investment attractiveness of renewable energy sources in the world are presented. Main obstacles impeding the utilisation of potential of renewable energy generation in Ukraine are pointed out from the standpoint of the global development trends, as the experience of economically developed countries are advised to be used for Ukraine. Conditions for investment activity in this field should be created (involving both domestic and foreign investments), stimulating state policy should be implemented, and an energy management based on the international experience should be developed. The problems of renewable energy sources in Ukraine are described, in particular, the presence of investment risk in terms of its components as general economic, legal and financial. In the most developed countries in terms of RES consumption direct public investment is a small proportion of total renewable energy financing, whereas private investment has the major share. A significant obstacle to the possibility of realizing such experience in Ukraine is the presence of investment risk, mainly caused by unstable political conditions (both internal and external). Energy management and monitoring activities of enterprises of various forms of ownership and branch affiliation should be introduced along with the necessity of attracting investments in renewable energy. It is expected that the results presented in this article may be useful for improving the renewable energy development policy both at the country level and at the level of a particular economic entity.
\end{abstract}

Keywords: energy management, investment risk, energy security, government policies, renewable energy, investments in renewable energy sources, bioenergy.

\section{INTRODUCTION}

The current stage of socio-economic development is characterized by reduction of available nonrenewable resources, deterioration of environmental conditions and growth of population, production volumes and humanity's energy needs on the global scale. The level of energy resources supply considerably influences social and economic development of a country and therefore defines the quality of life. The growing number of conflicts worldwide is partially caused by competition for 
natural resources, primarily the energy ones. Ensuring energy, ecological and food security are the key global issues of modern world. Therefore the development of renewable energy sources is the issue of utmost importance for each and every country globally.

Renewable energy resources are much more evenly distributed across our planet compared to nonrenewable ones. That is why the development of renewable energy can contribute to solution of the range of modern global problems: to improve the state of energy supply, to decrease the level of anthropogenic burden on environment (both due to the relatively high environmental friendliness of renewable energy in relation to nonrenewable ones and as a result of energy "decentralization"), to strengthen energy security of particular countries and liberalize international relations in the energy sector and, as a result, to optimize the geopolitical impact of the monopoly supply of non-renewable energy resources.

Renewable energy development requires a solution of a number of theoretical and practical tasks, among which is the choice of methodical approaches to assess the feasibility of renewable energy resources' utilisation and replacing them with non-renewable, selection of approaches to assess the value of economically feasible potential of these resources, and choice of allocation of capacities for their use, substantiation of construction of mutually beneficial (in economic and ecological aspects) relations with leading countries in the field of renewable energy sources, choice of behavior models of authority at different levels in the context of stimulating producers and consumers of renewable energy, justification of the need for implementation of energy management and monitoring in the activities of enterprises of all forms of ownership and types of economic activities.

Leading governmental and intergovernmental organizations, scientists in various branches of research pay considerable attention to different aspects of renewable energy sources. The International Renewable Energy Agency plays an important role in the process of data aggregation concerning the renewable energy sources in the global context $[1 ; 2]$. Research conducted by this intergovernmental organization is aimed at proving the necessity of investing in renewable energy sources and contributing to broad sustainable use of all renewable energy types (bioenergy, geothermal energy, hydroenergy, solar and wind energy) in the interests of energy safety and countries' economic growth globally.

Analysis of scientific literature shows that renewable energy in the context of its components is represented in the works of economic scientists from different parts of the world. It is related to the fact that the investment issues of this sector are undergoing research. Elaboration of renewable energy sources and minimization of expenditures in the process of projects implementation are under considerable attention.

\section{RESULTS}

The process of defining strategic benchmarks for renewable energy in Ukraine consists of the complex of interrelated stages: analysis of global tendencies in energy consumption and renewable energy development; strategic analysis of renewable energy capacity in Ukraine; research of conceptual basis of strategic development of energy sector; justification of strategic vectors of renewable energy development in the countries of the world and Ukraine using the opportunities of economic and legal instruments to influence this process.

The following methods were applied in the course of the research, such as calculation and construction method, grouping, comparison, modeling, prognosis and algorithm method.

Input data for analysis includes statistical data [3; 4; 5], documents on strategic development in various countries $[6 ; 7 ; 8 ; 9 ; 10 ; 11 ; 12]$, scientific literature on the methods to evaluate investment feasibility of new production development $[13 ; 14 ; 15]$.

The problem of efficient use of renewable energy sources is urgent and important from the viewpoint of harmonious economic and social development and environment protection. Nowadays development concepts in most countries stipulate considerable increase of the renewable energy share in the energy balance. Such alternate energy sources as solar thermal and power systems, wind 
generators, energy systems for biomass exploitation (wood and agricultural residues as raw materials for solid biofuel production), biogas production from the domestic and industrial wastes dumpsites, geothermal plants, etc.

During the last century global consumption of energy has increased rapidly (Figure 1), along with overall growth of GDP and population. Most rapid growth of energy consumption of the last 15 years has been observed in the Asian countries due to swift development of industrial production and economic development of the region. At the same time, there is a slight decrease in energy consumption in the countries of the European Union (-1\% 2017-2018), caused by mild weather conditions in winter and significant stimulating effects aimed at maintaining energy conservation by governments of most countries [5].

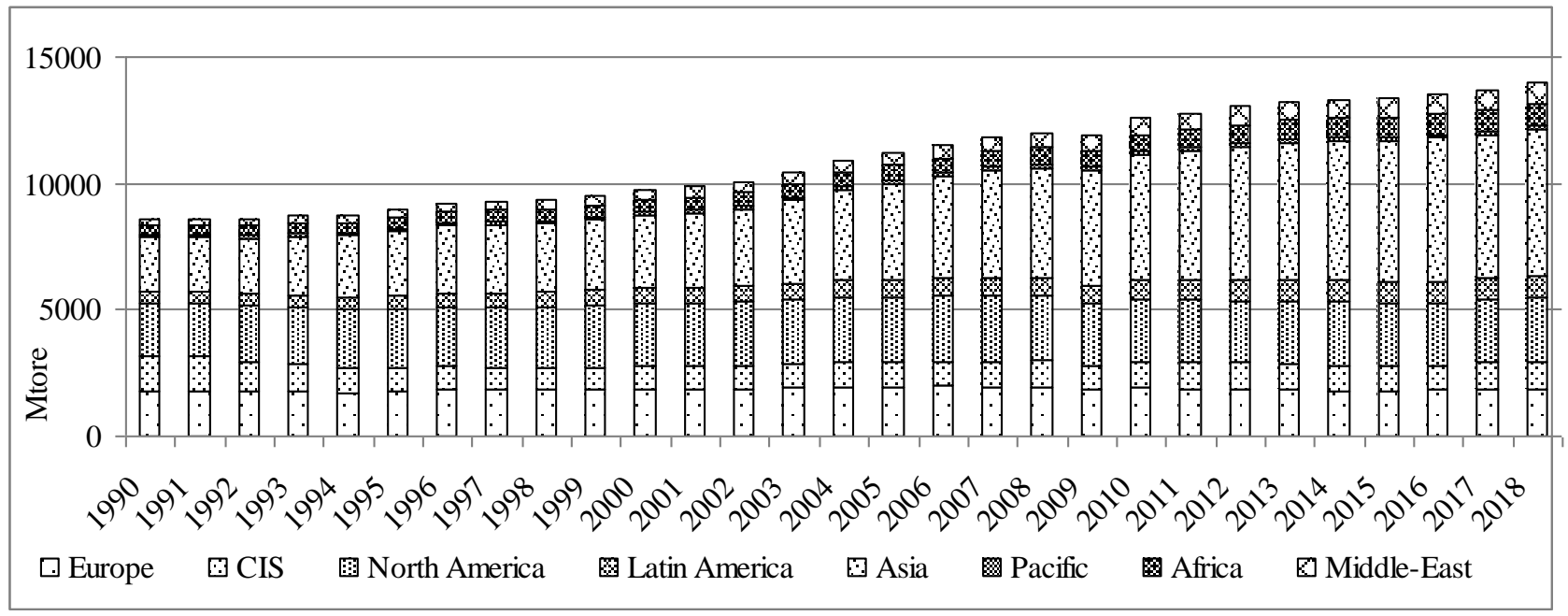

Fig. 1. Global energy consumption (generated from all energy sources) in the period from 1990 to 2018. Source: [5]

At the same time, in Ukraine the overall energy consumption (from all sources) has decreased more than twice during the last 25 years (Figure 2). The decrease is due to both the reduction of industrial production and to modernisation of production capacities, renovation of energy networks and growing understanding of the necessity to efficiently use the energy resources by state and economic entities. Currently key types of energy consumed by Ukrainians are generated from coal, gas and electricity (Figure 3).

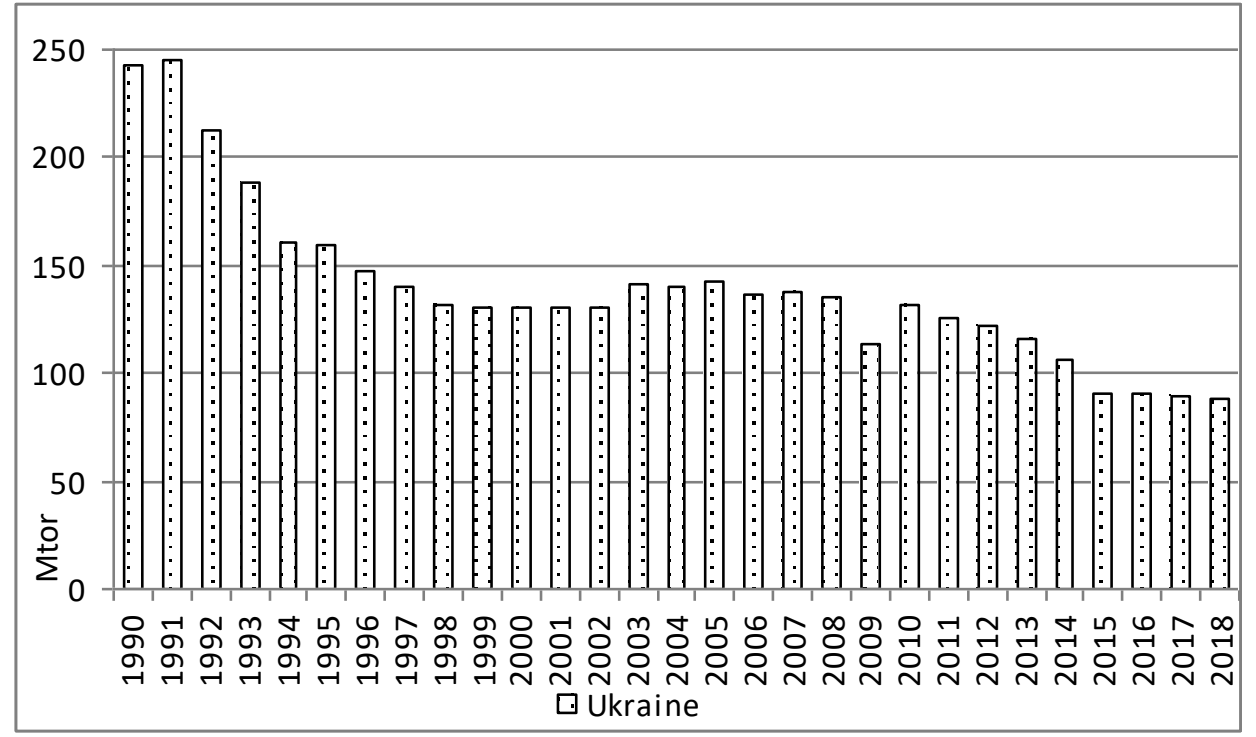

Fig. 2. Volumes of energy consumption in Ukraine from 1990 to 2018. Source: [5] 
Typological structure of consumed energy shows that oil, coal and gas show major share in consum ption in the world and in Ukraine (Figure 3). But the share of biomass in the structure of energy consumption in the world is $9 \%$, and in Ukraine it is 3\%.
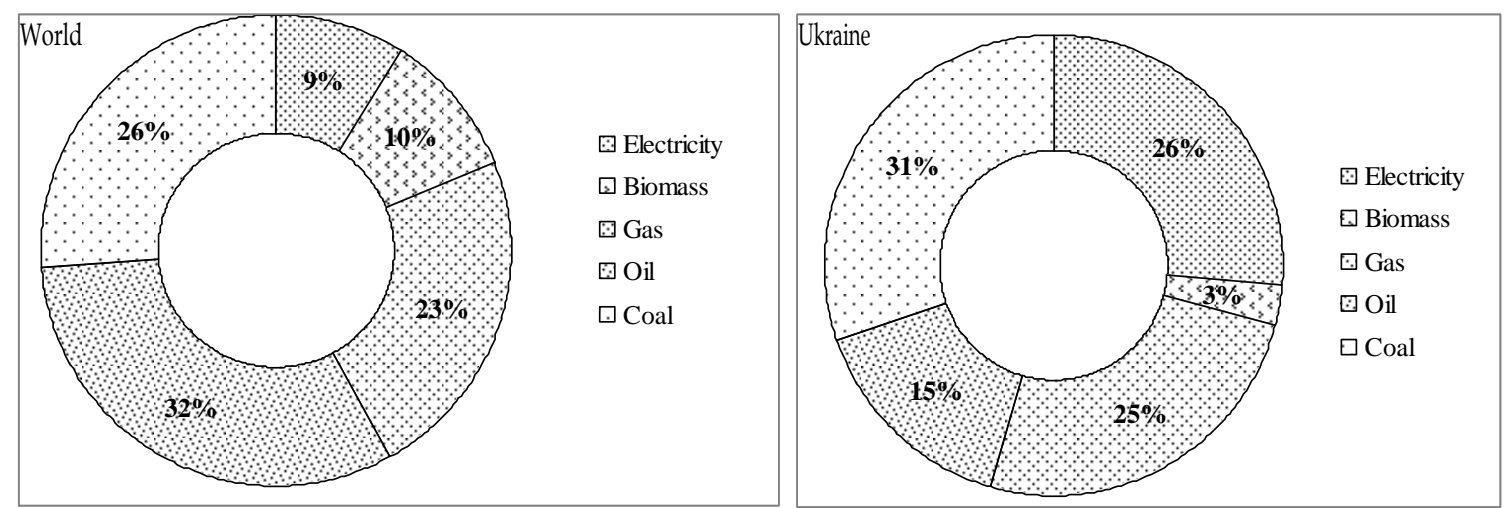

Fig. 3. Relative weight of global energy consumption according to generation sources in 2018 (World and Ukraine).Source: [4]

The above structure of energy consumption requires correction towards increasing the share of renewable energy sources. The potential reserves of the most deficit energy resources - oil and gas - are limited: according to expert assessments "the deposits available for development are expected to be exhausted in 50-60 years at the present level of their extraction; somewhat better situation is with coal reserves: at the present level of extraction coal reserves will will be enough for 450-500 years" [13]. Such tendencies stimulate countries to intensify generation of energy from renewable sources, with another major reason being the climate change and need for mitigation of greenhouse gas emissions, of which the energy sector is the primary emmitant.

This need is especially acute for Ukraine in the context of the fight for energy security from the Russian Federation. Therefore, renewable energy sources development is the decisive matter in the context of overcoming the risks faced by Ukraine country in current conditions [14] and achieving national security.

Ukraine should implement the experience of five world leaders in production of energy from renewable sources such as China, USA, Germany, Japan and India. These countries have taken into account swift paces of exploitation of renewable energy sources and now consistently accomplish the planned tasks on diversification of energy balances towards increasing the share of renewable energy sources.

The share of renewable energy in the global context is increasing in the past several decades. Thus, in 2018 the share of renewable energy in the global production of electrical energy amounted to $26 \%$, and non-renewable respectively $74 \%$, and in Ukraine the share of renewables is only $9 \%$ (Figure 4)
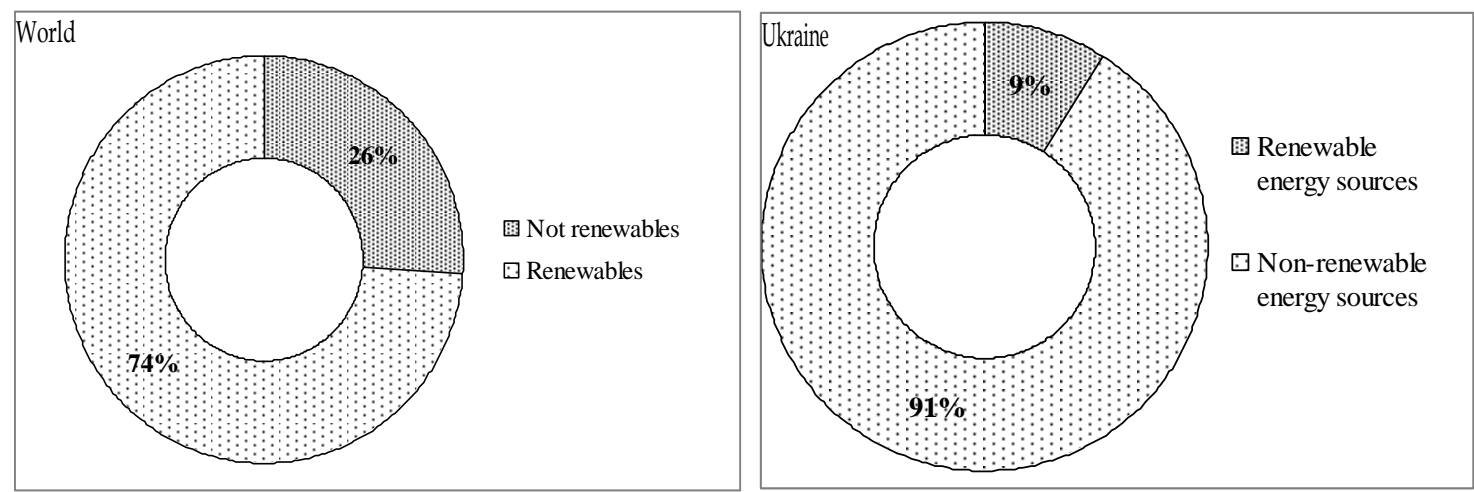

Fig. 4. The share of renewable energy in the global production of electrical energy in 2018

(World and Ukraine). Source: [4] 
Global trends show that "Reducing the costs of renewable energy sources and the policy of their support led to an increase in the share of renewable energy in the global energy balance ( +0.8 points)" [5]. Despite the political assistance and awareness of society, the level of exploitation of renewable energy sources in Ukraine is at a low level compared to global trends (Figure 5). At the same time Ukraine has a potential for increase of the share of renewable energy sources, which is proven by calculations of relevant governmental entities and scientific research.

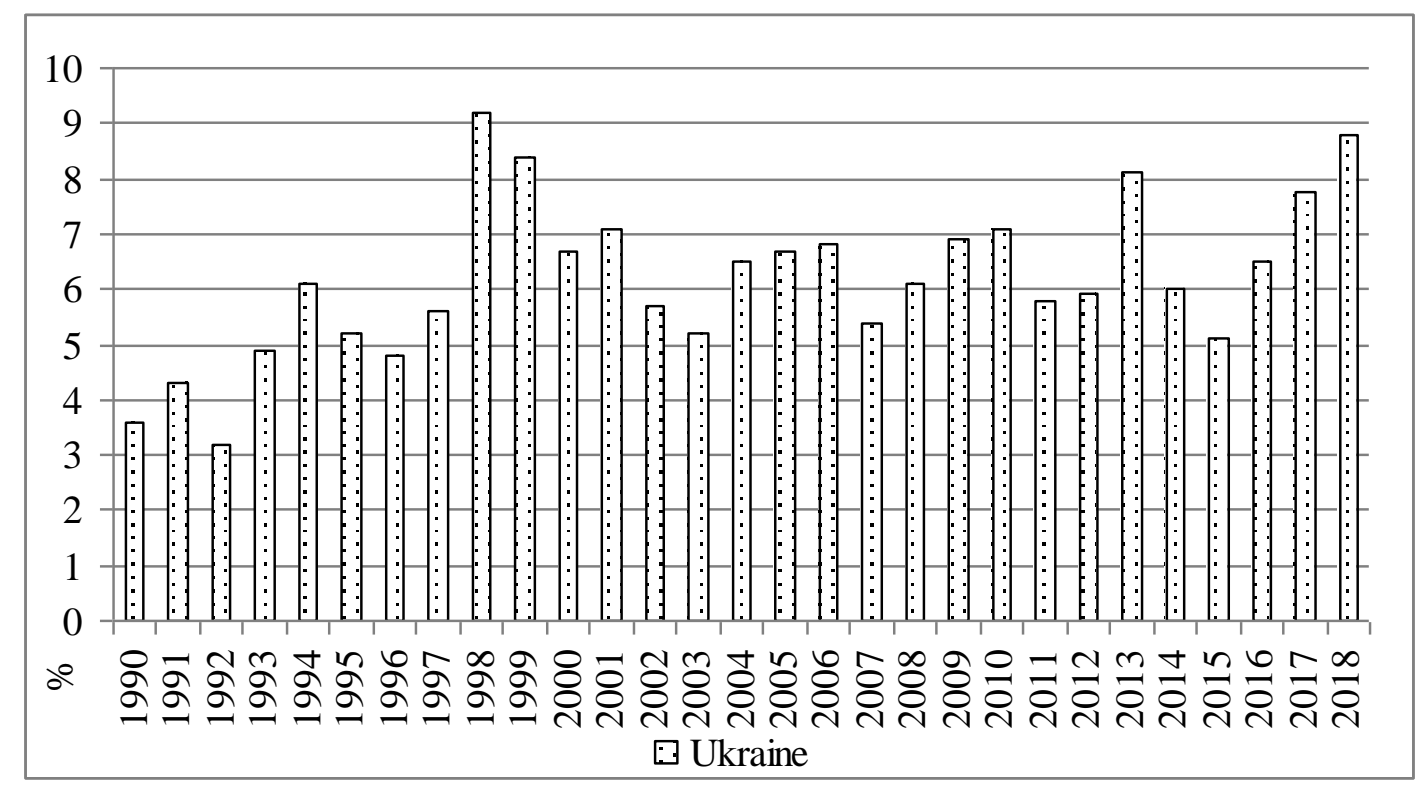

Fig. 5. Generation of electrical energy from renewable sources in Ukraine in 2000-2018. Source: [5]

According to calculations of State Agency for Energy Efficiency and Energy Saving of Ukraine, country has a considerable technically achievable capacity of energy supply generation from renewable sources and alternative types of fuel, which annualy equal ca. $98 \mathrm{mln}$ tonnes of fuel [16]. But dynamics of alternative energy development in Ukraine is not sufficient to meet the planned targets of 2035 Energy Strategy of Ukraine "Safety, energy efficiency, competitive ability" [6], however there are certain aspirations towards that end.

Prospects for renewable energy development in Ukraine and its scientific and industrial capacity contribute to significant increase of growth paces of renewable energy exploitation volumes in the country. However, in order to achieve this goal the conditions for stimulation of investment activity in the sphere have to be created, as well as the energy management has to be implemented. This will attract both domestic and foreign investment, enhance stimulating state policy, and develop energy management based on the use of international experience.

The role of various types of stimuli in the global scale can be observed on the basis of global tendency of renewable energy sources development. Global annual investment in renewable energy rose steadily in 2013-2015, peaking at USD 330 billion in 2015 before falling to USD 263 billion in 2016. While annual investment declined in 2016, capacity additions in the same year were up from 2015, which is stipulated by the gap between the date of funding and launching of renewable energy projects (e.g. 1 year and seven months for bioenergy). This is partially due to declining costs and partially to the time lag between financial closure (i.e., the time of investment) and the completion of construction, after which an installation becomes operational. Policy changes contributed significantly to global investment trends. The peak in 2015 was partially driven by a rush to complete projects before an expected fall in policy support in key markets [5;3].

The number of countries promoting renewable energy through direct policy support has tripled from at least 48 in 2004 to at least 147 today, and more and more developing and emerging countries are adopting new targets and policies for renewables (Figure 6). 


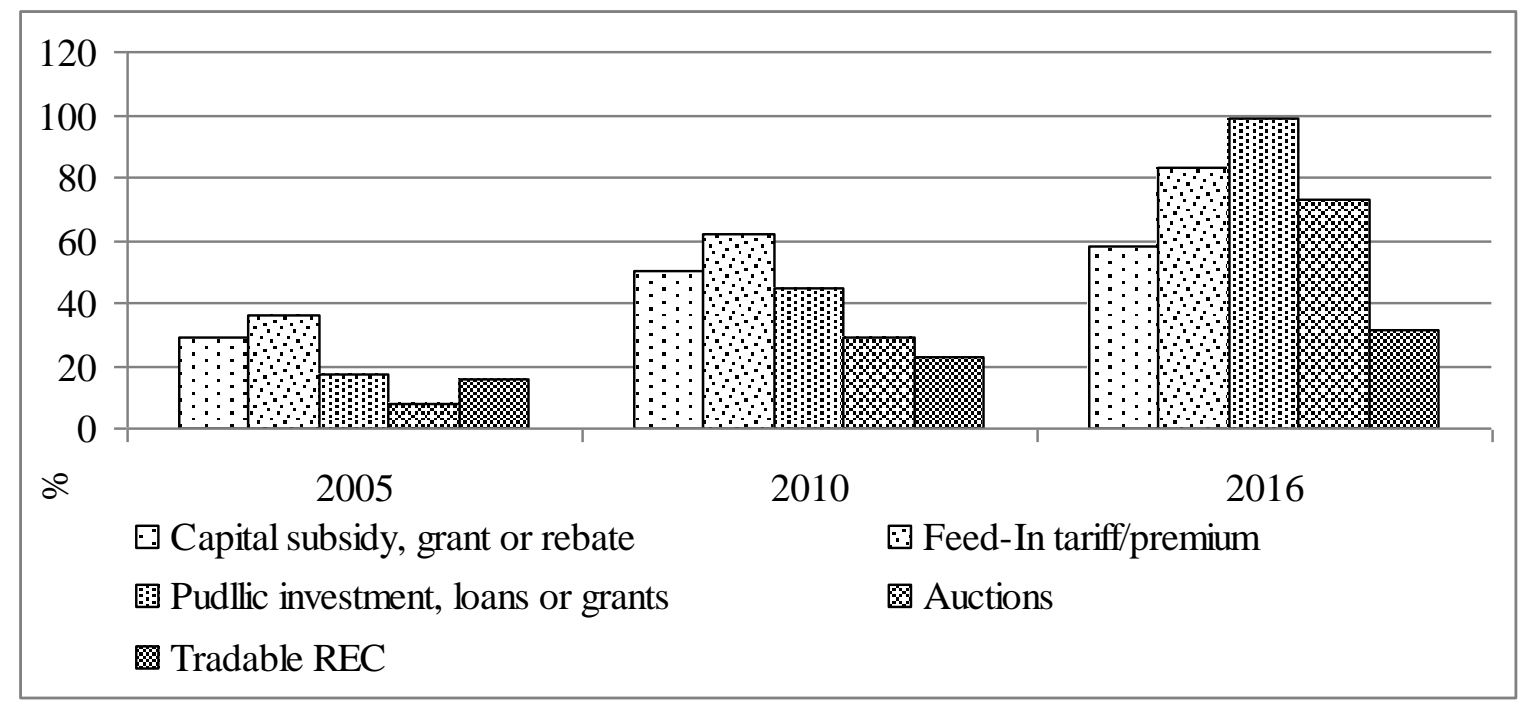

Fig. 6. Number of countries adopting renewable energy policies, by policy type during 2005-2016. Source: [1]

Direct public investments has typically constituted a small share of total renewable energy finance, the bulk of renewable energy investment - more than 90 is financed from private sources [1]. And to attract private investment in the RES sector in Ukraine it is necessary to minimize investment risks.

Figure 7 shows global flows of renewable energy funding along the investment cycle in 2015 and 2016 taking into account the certain spectrum of sources, instruments, regions and technologies as well as differences between the sources of public and private funding.

International Renewable Energy Agency deems the following matters as the key factors of competitive ability and investment attractiveness of renewable energy as a branch: favourable regulatory and institutional framework; low offtake and country risks; a strong, local civil engineering base; favourable taxation regimes; low project development costs; and excellent resources $[1 ; 2]$.

These key factors promote renewable energy development in the developed countries of the world, however existing investment risk is a huge problem in Ukraine. Therefore, we deem it necessary to introduce energy management and monitoring into the activity of enterprises of various ownership types and nature of industry along with the necessity to attract investment into the renewable energy. As far as energy management and monitoring are directed at maintenance of efficient use of fuel and energy resources and at ongoing process of energy supplies consumption supervision, their introduction reduces the need for additional investment in nonrenewable energy sources and rather attracts investors to develop renewable energy sources. In Ukraine, however, the big objective problem is the presence of investment risk in terms of its components as general economic, legal and financial. Given the impossibility of overcoming them in the short term, the relevant authorities and business entities should look for ways to develop renewable energy and energy saving as an alternative to additional investment in the form of investment. Therefore, along with the need to attract investments in renewable energy, we consider it expedient to introduce energy management and monitoring in the activities of enterprises of various forms of ownership and industry affiliation. Energy management and monitoring are aimed at ensuring the rational use of fuel and energy resources and the continuous process of tracking their consumption in order to make decisions economically and environmentally friendly solutions. 


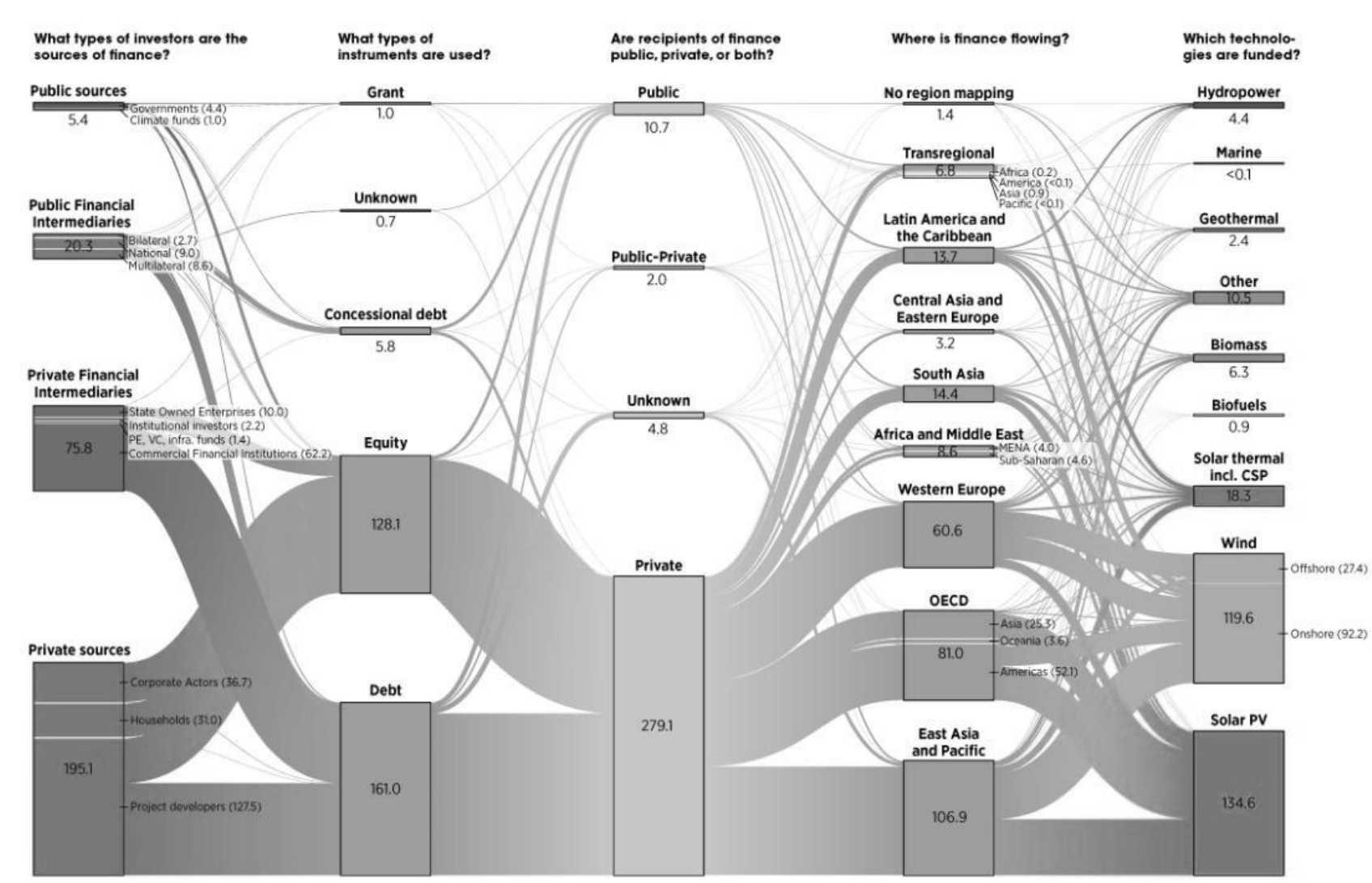

Fig. 7. Global landscape of renewable energy finance 2015/2016, USD billion. Source: [1]

According to the data of State Agency for Energy Efficiency and Energy Saving of Ukraine [17], introduction of energy management will enable achievement of the following rates without additional investment in the activity of budget institutions: from 5 to 8 of energy resources saving due to energy efficient behaviour of consumers; up till 20 of energy consumption reduction due to establishment of efficient objects' exploitation.

Ukrainian liabilities under the Paris Agreement, EU-Ukraine Association Agreement and the Energy Community Treaty stipulate conducting of the activity directed at the most rapid launching of instruments that significantly influence the rational consumption of energy resources in Ukraine. Taking into account the experience of developed countries, there is no alternative for creation and development of energy management systems for improvement of economy energy efficiency.

2012/27/EC Directive provides that: “Energy audits should take into account relevant European or International Standards, such as EN ISO 50001 (Energy Management Systems), or EN 16247-1 (Energy Audits), or, if including an energy audit, EN ISO 14000 (Environmental Management Systems) and thus be also in line with the provisions of Annex VI to this Directive as such provisions do not go beyond the requirements of these relevant standards" [11].

There is the State Standard ISO 50001:2014 “Energy management systems - Requirements with guid anceforuse" in Ukraine, which is the written translation of international standard ISO 50001:2011. Saving of finances due to reduction of energy consumption and promotion of renewable energy exploitation is an essential effect of this standard introduction [10]. On the basis of ISO 50001 standard the instruments of evaluation, analysis and verification of management activity results' verification in energy consumption emerge. The standard is based on methodology known as the cycle of continuous improvement "Plan - Do - Check - Act" and introduces energy management into everyday activity (practice) of organizations (Figure 8). 


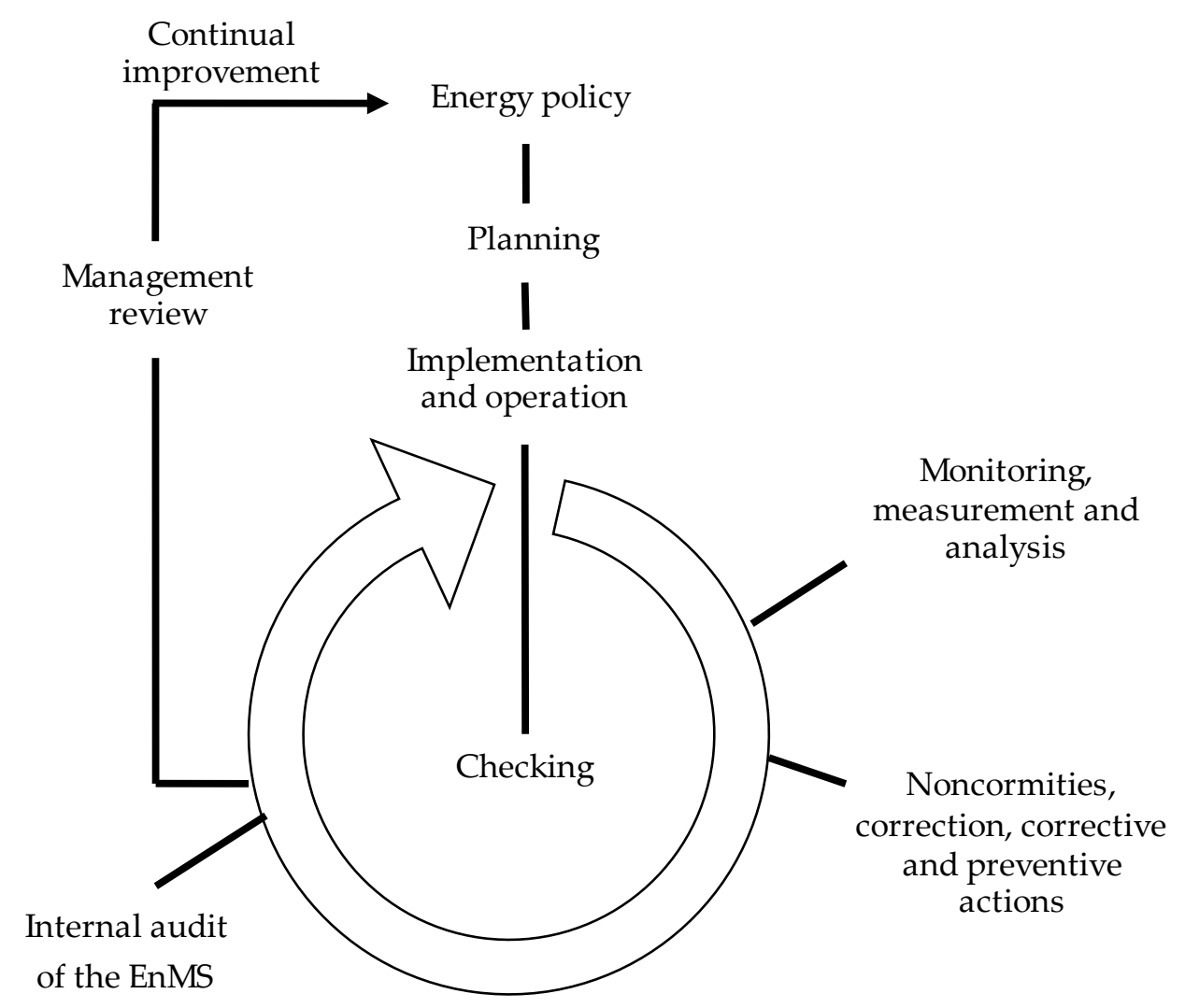

Fig. 8. International standard "Energy management systems" ISO 50001. Source: [11]

An approach on the basis of PDCA cycle can be described as following:

- plan - analyze the energy parameters and define the basic level of energy characteristics and energy efficiency indicators; set goals and tasks and develop the measures necessary for achievement of results to improve energy characteristics in accordance with the energy policy of an organization;

- do - introduce the plan of activities in the sphere of energy management;

- check - conduct monitoring and measuring of key activity characteristics that define energy characteristics on energy policy, goals and documented results;

- act - take measures to constantly improve the energy characteristics and parameters of energy efficiency.

Application of the standard on the global scale contributes to more efficient use of available energy resources, promotion of competitive ability and reduction of greenhouse gas emissions and other influences on environment due to the use of renewable energy. Therefore this standard can be applied regardless of the type of used energy.

Major idea of ISO 50001: 2011 introduction is not to establish the plan of actions but rather the management system with themechanisms of monitoring, analysis and corrective action s. As the result, major function of energy management system (energy consumption management towards improvement of its efficiency) is realized.

For different businesses, this can be manifested differently: someone is making efforts to save on non-renewable energy sources; someone, based on available biomass resources, diversifies the energy supply, and so on.

Implementation of fully functioning energy management systems is impossible without modern technologies of data collection, information processing and consumption management. These will be issues for our further research. 


\section{CONCLUSIONS}

Renewableenergy can strengthen the energy security of many countries, and the efforts of most of them give positive results. An analysis of global trends in energy consumption and renewable energy development showed that those countries in which the state support for the renewable energy sector shows the dynamics of increasing their share in the structure of the energy balance.

The main prerequisites for the use of renewable energy resources are their lower impact on the natural environment com pared to non-renewable, the relative unlimited reserves of these resources and the potential for boosting business activity and economic growth in countries where renewable energy are to develop.

It was found out that in the most developed countries in terms of RES consumption direct public investment is a small proportion of total renewable energy financing, whereas private investment has the major share. A significant obstacle to the possibility of realizing such experience in Ukraine is the presence of investment risk, mainly caused by unstable political conditions (both internal and external).

The process of developing renewable energy in Ukraine, as announced in the energy strategy and a number of regulatory acts, is an urgent problem. The economic and political situation that arose in Ukraine caused a dynamic change in the country, which had a particular impact on its energy security. In order to strengthen the country's energy independence from imported non-renewable energy sources and energy security of a separate enterprise (including economic and environmental), development of renewable energy sources is necessary. In this case, special attention should be paid to such an instrument as energy management, the ultimate goal of which is to form a behavior model that aims at increasing the efficiency and environmental friendliness of energy use.

\section{REFERENCES}

[1] International Renewable Energy Agency, 2018a. Global Landscape of Renewable Energy Finance. Available at: http://www.irena.org/-/media/Files/IRENA/Agency/Publication/2018/Jan/IRENA_Global_landscape _RE_finance_2018.pdf

[2] International Renewable Energy Agency, 2018b. Renewable Power Generation Costs in 2017. Available at: https://www.irena.org/-/media/Files/IRENA/Agency/Publication/2018

/Jan/IRENA_2017_Power_Costs_2018.pdf

[3] Bloomberg New Energy Finance, 2017. Renewable energy projects and asset finance databases. Available at: https://www.bnef.com/core/login?requested=2Fassetfinancing2F2520p

[4] Global Energy Statistical Yearbook, 2019. Share of renewables in electricity production. Available at: https://yearbook.enerdata.net/renewables/renewable-in-electricity-production-share.html

[5] Global Energy Statistical Yearbook, 2019. Total energy consumption. Available at: https://yearbook.enerdata.net/renewables/renewable-in-electricity-production-share.html

[6] Cabinet of Ministers of Ukraine, 2017. 2035 Energy Strategy of Ukraine "Safety, energy efficiency, competitive ability". Available at: http://zakon2.rada.gov.ua/laws/ show/605-2017-D180/paran2\#n2

[7] EUR-Lex, 2014. Communication From the Commission to the European Parliament, the Council, the European Economic and Social Committee and the Committee of the Regions. A policy framework for climate and energy in the period from 2020 to 2030. Available at: https://eur-lex.europa.eu/legal-content/EN/TXT/ ?uri=CELEX:52014DC0015

[8] Institute of Renewable Energy of the NAS of Ukraine, 2012. Strategies of renewable energy development. Available at: https://drive.google.com/file/d/0B-NwxLyWNlANeThibW9RbGdJdW8/view

[9] Institute of Renewable Energy of the NAS of Ukraine, 2016. Potential for the use of renewable energy sources. experience of developed countries on renewable energy development. Available at: http://www.ive.org.ua/wp-content/uploads/kudrya-17052016.pdf 
[10] Ministry of economic development of Ukraine, 2015. National standard of Ukraine Energy saving. Energy management system. Requirements and instructions for the use (ISO 50001:2011, IDT) DSTU ISO 50001:2014. Available at: http://online.budstandart.com/en/catalog/doc-page?id_doc $=60876$

[11] Official Journal of the European Union, 2012. Directive 2012 / 27EU of the European Parliament and oF the Council of 25 October 2012 on energy efficiency, amending Directives 2009/125 / EC and 2010/30 / EU and repealing Directives 2004/8 / EC and 2006/32 / EC. Available at: http://saee.gov.ua/sites/default/files/ UKR_Directive_27_2012_2.doc

[12] Publications Office of the European Union, 2011. Energy 2020. A strategy for competitive, sustainable and secure energy. Available at: http://eur-lex.europa.eu/legal-content/EN/TXT/?qid=1409650806265\&uri= CELEX: 52010DC0639

[13] Hlobystov Ye.V. State ecological policy of Ukraine in conditions of authorities' decentralization. DU IEPCR NAN of Ukraine, Kyiv, 2016. (in Ukraine)

[14] Popadynets N.M., Maksymiv Yu.V. Development of domestic solid biofuel market in Ukraine under current conditions. Economic Annals-XXI, 159 (5-6) (2016), 93-96. doi: 10.21003/ea.V159-20 (in Ukraine)

[15] Salerno M., Gallucci F., Pari L., Zambon I., Sarri D. and Colantoni A. Costs-benefits analysis of a small scale biogas plant and electric energy production. Bulgarian Journal of Agricultural Science, 23 (3) (2017), 357-362.

[16] State Agency for Energy Efficiency and Energy Conservation of Ukraine, 2017a. Technically Achievable Potential to Produce Fuels from Renewable Energy Sources and Alternative Fuels. Available at: http://saee.gov.ua/uk/activity/vidnovlyuvana-enerhetyka/potentsial

[17] State Agency for Energy Efficiency and Energy Saving of Ukraine, 2017b. Energy audit and management. Available at: http://saee.gov.ua/uk/business/energetichny-audit-ta-manadzhment

Address: Valentyna Yakubiv, Yuliia Maksymiv, Iryna Hryhoruk, Iryna Piatnychuk, Vasyl Stefanyk Precarpathian National University, 57, Shevchenko Str., Ivano-Frankivsk, 76018, Ukraine;

Nazariy Popadynets, M. I. Dolishniy Institute of Regional Research of NAS of Ukraine, 4, Kozeletska Str., Lviv, 79026, Ukraine;

E-mail: yakubiv.valentyna@gmail.com, yuliia.maksymiv@pnu.edu.ua, iryna.hryhoryk@pnu.edu.ua, irynapy@gmail.com, popadynets.n@gmail.com

Received: 07.08.2019; revised: 05.12.2019.

Якубів Валентина, Максимів Юлія, Попадинець Назарій, Григорук Ірина, П'ятничук Ірина. Розвиток відновлюваних джеред енергії в контексті енергетичного менеджменту. Журнал Прикарпатського університету імені Василя Стефаника, 6 (3-4) (2019), 77-87.

У статті розгдядаються світові тенденції споживання енергії та виробництва відновлюваної енергії. Світові практики фінансування виробництва відновлюваної енергії проаналізовано відповідно до таких категорій: джерела фінансування, види політичних інструментів, типи реципієнтів (державні чи приватні) та види технологій, що отримують фінансування. Представлені ключові фактори, які впливають на інвестиційну привабливість відновлюваних джерел енергії у світі. Основні перешкоди, що затримують використання потенціалу відновлюваної енергії в Україні, вказано з позицій світових тенденцій розвитку, оскільки досвід економічно розвинених країн рекомендується використовувати для України. Особливо важливим є створення умов для інвестиційної привабливості у цій галузі (із залученням як внутрішніх, так і закордонних інвестицій), також слід здійснювати стимудяційну державну політику та розвивати енергетичний менеджмент на основі міжнародного досвіду. Охарактеризовано проблеми відновлюваних джерел енергії в Україні, зокрема, наявність інвестиційного ризику з точки зору його складових як загальноекономічних, правових та фінансових. Прямі державні інвестиції у більшості розвинутих з точки зору споживання ВДЕ країн, становдять 
незначну частку від загального обсягу фінансування відновлюваної енергії, а основну питому вагу становлять приватні інвестиції. Суттєвою перешкодою для мождивості реалізації такого досвіду в Україні є наявність інвестиційного ризику що насамперед пов'язаний з нестабільними політичними умовами (як внутрішнього, так і зовнішнього характеру).

Діяльність 3 управління енергетикою та моніторингу підприємств різних форм власності та галузевої приналежності повинна бути запроваджена разом з необхідністю залучення інвестицій у відновлювані джерела енергії. Очікується, що результати, представлені в цій статті, можуть бути корисними для вдосконалення політики розвитку відновлювальної енергетики як на рівні країни, так і на рівні конкретного суб'єкта господарювання.

Кдючові слова: енергетичний менеджмент, інвестиційний ризик, енергетична безпека, державна політика, відновлювані джерела енергії, інвестиції у відновдювані джерела енергії, біоенергетика. 